\title{
Protection of Some Rare and Critically Threatened Medicinal Plants in The Azerbaijan Flora
}

\author{
S. Ibadullayeva \\ Institute of Botany of the Azerbaijan National Academy of Sciences \\ A.Mustafayev \\ Ministry of Ecology and Natural Resources of the Azerbaijan Republic
}

M.Shahmuradova

Azerbaijan State Agrarian University

E-mail: sayyarajamshid@yahoo.com

Received: April 23, 2012 Accepted: May 7, 2012

doi:10.5296/jbls.v4i1.2827 URL: http://dx.doi.org/10.5296/jbls.v4i1.2827

\begin{abstract}
The flora of Azerbaijan differs by its great variety. One hundred and fifty families comprising of 1000 genera and 4700 species make $70 \%$ of Caucasus flora. Out of which more than 1400 species have medicinal (315 species - alkaloids, 150 species - coumarins, 1000 - essential oils, and flavanoids). In the Middle Ages 300 wild-growing species were used for treatment in Azerbaijan medicine; now only 135 species have access in the State Pharmacopeia.

The plants are continuously increased at a result of in-situ conservations of medicinal plants. Their decrease has been prognosticated preliminarily. It was realized that young and generative development of the vegetable specimen in the populations belonged to Urtica dioica L. The amount of the specimen at cinil and subcinil phases in the Astragalus dasyanthus Pall. species was twice more than it was in immature and generative phases of the plant that cause gradual decrease of these populations. Restoration activities should be carried out for in-situ conservation of such plants.

The article is for the conservation and protection of medicinal plants of the region. Methods of population awareness and education of students, teachers and local people is ecology recommended along with the administrative measures.
\end{abstract}


Keywords: Medicinal herbs, Plant resources, Population, Phytocenology, Rare and threatened species.

\section{Introduction}

Republic of Azerbaijan - is the biggest country in the Caucasus Region of Eurasia. It is situated in Caucasus - in the basin of the Caspian Sea that is on the crossing of Europe and Central Asia. Its area is $86.600 \mathrm{~km}^{2}(11.5 \%$ - forests, $1.6 \%$ - water basins, $50 \%$ - cultivated lands, including: $27 \%$ pastures, $36.9 \%$ other lands). Azerbaijan has got a rich flora and a harmonious vegetation cover in the area. There are about 1.000 genera containing all plant groups, about 4700 plant species with higher spore, naked and covered seeds, flowers belong to 200 families, in this ancient Country making nearly $70 \%$ of the Caucasus flora; 5\% (370 species) of them are regional endemic and rare plants (Akhundov, 1972; Hajiyev and Musayev, 1996; Asgerov, 2005-2011).

The physical and geographical environmental conditions of Azerbaijan characterized by a variety of climates, soils, abundance of water sources and solar radiation etc. - favour the abundant and rich flora source for many purposes including medicinal therapy. Species were collected during long-term expedition surveys covering all natural and geographical areas of Azerbaijan: the Great Caucasus, the Small Caucasus, the East-Western Lowland, the Steppe Plateau, Gobistan, Talysh as well the Nakhichevan AR.

The floral biodiversity has perennial grasses $(66,4 \%)$, on the $2^{\text {nd }}$ place annual ephemerals and ephemeroids $(23,4 \%)$, the rest of them are other plants. The Azerbaijan flora has 435 species of trees and shrubs. These plants have formed a special plant cover in Caucasus Region as ancient, forest, desert, semi-desert, Caucasian, boreal, steppe, xerophyl, adventive et.al. can be met (Hajiyev, 2004).

The chemical structure and pharmaceutical properties of the collected plant species have been studied throughout several expeditions. As a result 800 species of medicinal, 850 species of essential oil plants have been collected and defined during the initial inventory. More than 1545 medicinal plants (including 315 species of alkaloid, 150 species of coumarine, and 1000 species of essential oil) represented 178 families and 740 genera have been ascertained in the Country.

This problem is also actual and urgent because of the stresses of anthropogenic factors that cause threat during recent decades and global ecological changes have more increased; biodiversity sharply began to decrease by ecosystems degradation; many valuable species have been lost or they are under threat to become lost.

One objective of the research was a study of the current state of medicinal herb populations much more used in Azerbaijan flora.

Protection of rare and critically threatened species in accordance with the Red List requirements has been evaluated.

\section{Material and methods}


Samples of rare and threatened food plant species were taken as a test subject. Classical and update methods have been used during the monitoring activities [Lavrenko, 1959; Davis, 1993]. Seed samples of the disappearing species were delivered to the National Gene Bank for long-term conservation.

Recently a number of arrangements are being implemented for the conservation of species with a limited areal spread in all over the world. A Red List of the threatened species as well as methods for their categories and criteria have been composed by the IUCN Council and a clear system was worked out to classify critically threatened species. During the monitoring activities 3.1 version of the IUCN has been used in the evaluation of plants status [IUCN, 2003].

For precise studies of the spread species, certain territories were marked and 15-20 examples were selected and taken picture of them. It has been used different systems for studying of plants life styles [Raunkier, 1937; Serebryakov, 1964].

\section{Experimental Part}

Thus the research was carried out in different areas beginning from arid semi-desert landscapes up to Alpine grasslands of Azerbaijan show that areal of certain species and varieties met in every step up to the recent days are getting narrower and their natural resources disappearing.

That is why there are such kind of species that were collected and used by the people before in the flora they are very seldom met in the wild at presesnt. Current status of the group of wild vegetable widely used as medicinal and food herb by the people has been studied by us according to the IUCN category and criteria [Ibadullayeva et.al., 2011]. In the following Table information about the current status of some medicinal herbs got narrower areals and even threatened in the flora of the Nakhichevan Autonomous Republic have been shown (Table 1).

Table 1. Current state of rare and threatened medicinal herbs in the Azerbaijan Flora

\begin{tabular}{|l|l|c|}
\hline № & \multicolumn{1}{|c|}{ Name of the plants } & IUCN criteria \\
\hline 1. & Astragalus prilipkoanus Grossh. & VU C2a(i) \\
\hline 2. & A.regelii Trautv. & VU C2a(i) \\
\hline 3. & A.szovitsii Fisch. \& C.A.Mey. & VU C2a(i) \\
\hline 4. & Astracantha aurea (Willd.) Podlech & NT \\
\hline 5. & A.karjaginii (Boriss.) Podlech & VU C2a(i);D2 \\
\hline 6. & Allum akaka S.G. Gmel. ex Schult. et Schult. & VU B2bc(i) \\
\hline 7. & Allum woronowii Miscz. ex Grossh. & EN B2ab(iii) \\
\hline 8. & Pyrethrum komarovii Sosn. & VUA2cd \\
\hline 9. & Cachrys microcarpa Bleb. & EN A2ac+C1 \\
\hline 10. & Cicer anatolicum Alef. & VU B1b(i,v)c(i, iii) \\
\hline 11. & Crataegus orientalis Pall.ex Bieb. & NT \\
\hline
\end{tabular}




\begin{tabular}{|c|c|c|}
\hline 12. & C.pontica C.Koch & NT \\
\hline 13. & Crocus speciosus Bieb. & VU B2bc(ii,v) \\
\hline 14. & Ceterach officinarum Willd. & NT \\
\hline 15. & Dryopteris filix- mas (L.) Schott. & NT \\
\hline 16. & Daphne transcaucasica Pobed. & VU A1d \\
\hline 17. & Euphorbia grossheimii Prokh. & NT \\
\hline 18. & Humulus lupulus L & VU B2ab \\
\hline 19. & Heracleum albovii Manden & VU B1a(i)c(iii);C2(i) \\
\hline 20. & Hippophae rhamnoides L. & NT \\
\hline 21. & Hypericum linarioides Bosse & VU A1c; B1ac(ii) \\
\hline 22. & H. formosissimum Takht. & VU A1c; B1ac(ii) \\
\hline 23. & Juniperus sabina L. & EN B1ab(ii,iii) \\
\hline 24. & Juniperus foetidissima Willd. & CR A4acd \\
\hline 25. & Juniperus communis L. & NT \\
\hline 26. & Juniperus excelsa Bieb. & EN A2acd \\
\hline 27. & Jurinea spectabilis Fisch. \& C.A. Mey. & CR A2cd \\
\hline 28. & Pyrethrum kotschyi Boiss. & VU A3cd \\
\hline 29. & Hippophae ramnoides $\mathrm{L}$. & VU B1ac \\
\hline 30. & Pulsatilla violacea Rupr. & NT \\
\hline 31. & Rosa nisami Sosn. & EN B2ac(iii) \\
\hline 32. & R.karjaginii Sosn. & CR A3c; $\quad$ C2a(i) \\
\hline 33. & R.sosnovskyana Tamamsch. & VU A2cd \\
\hline 34. & R.pimpinellifolia $\mathrm{L}$. & EN B2ac \\
\hline 35. & R.tuschetica Boiss. & VU B1bc \\
\hline 36. & Rubus ibericus Juz. & NT \\
\hline 37. & Sorbus luristanica Bornm. & EN A2ac \\
\hline 38. & Sorbus persica Hedl. & EN A2ac \\
\hline 39. & Sorbus takhtajanii Gabr. & EN A2ac \\
\hline 40. & S. turcica Zinserl. EN & EN A2ac \\
\hline 41. & Thymus migricus Klok. \& Shost. & VU C2a \\
\hline 42. & Valeriana alliarifolia Adams. & VU A3bc \\
\hline
\end{tabular}

Recently we evaluated the threats to plants for their in-situ. It is known that first of all information about the local exploitation of the natural populations of useful plants then their resources and productivity should be studied in order to protect the wild. Afterwards, ontogenetic status of the plant should be researched and their life-styles, type of the life environment and bioecological features should be studied to conserve their natural resources.

At the cenological evaluation of the populations age indexes have been identified through ontogenes evaluation of the plants in all phases that is of the factors creating opportunity of prognosing natural status of the plant in future. For instance, let us pay attention to Urtica dioica species known as medicinal herb and widely used by the people.

During the investigation 10 populations have been worked in the geographical region 
Gunnut-Gapijig of the Nakhichevan AR, in the territory of Yeni Yol of the Great Caucasus, in Shahriyar Forest of Gek-Gel Region of the Small Caucasus. Spread area and bioecological features of $U$. dioica species at each 10 registered populations have been studied.

U.dioica is a perennial plant, it is considered as plant of medicinal, food and forage significance as well as is very important for people. As this plant is widely used in Azerbaijan that is why study of the current status of the plant populations interested us very much.

The research activities have being carried out at all phases in the spring-autumn season. Role and phytocenological structure of the U.dioica species in the vegetation type have been studied, it was realized that the plant belongs especially to mesophyte ecological group in the flora as well as it is of valley-meadow, flood-lands elements. During the researches spread of the species in miscellaneous herb formations of grassland, bush, and forest vegetation within the plant grouping were observed in each three regions. Populations in the following amount were selected and evaluated as: Shahriyar Forest of the Small Caucasus (1-3), Yeni Yol of the Great Caucasus (4-6) 3, in the Nakhichevan AR (7-10) 4. In 2011 a comparative criteria was shown by using conception of ontogenesis of U.dioica species and registering them at immature (im), virginil (v), young generative (g1), middle age (g2), aged (g3), sub-senile (ss) and senile (s) periods. On the result according to the research method of the populations, materials collected at different phases of the plant their ontogenesis structure have been identified; development phases at plant individuals entirely defined, the obtained conclusions were specified on the diagramme (fig.1).

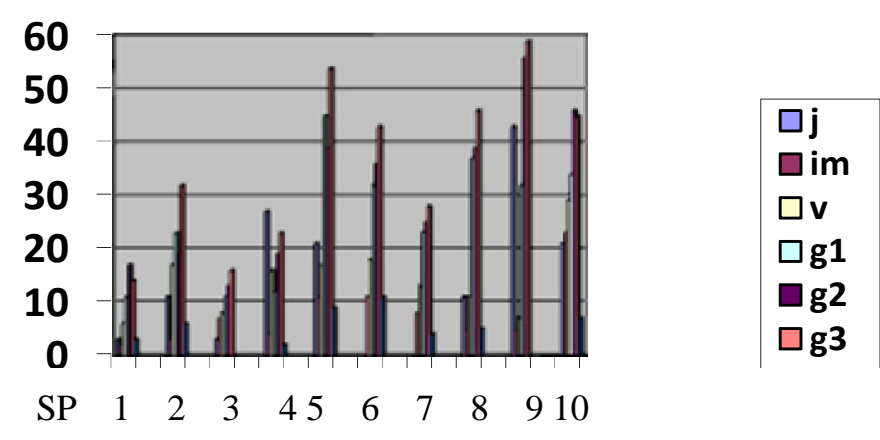

Figure 1. Ontogenetic structure of Urtica dioica species in 2009

As it is seen in the diagramme the generative development phase of ontogenesis mainly is characteric for all populations. Individuals belonged to sinil and subsinil periods in some populations (for eg.: at 3 and 9) were not met. Even increase of amount of those individuals belonged to the juvenile period at the populations were registered (at $3-33$ plants, at $9-43$ plants etc.). $\mathrm{g}_{1}, \mathrm{~g}_{2}$ and $\mathrm{g}_{3}$ phases are characteristic for all populations (260-360 plant individuals) and it tells about the stable development of the plant. Ascertaining of individuals belonged to hydrocyanic and sub-hydrocyanic periods at $3.46 \%$ of the plants spread in the natural populations tells us that these plants are young.

Structure of the ontogenesis of U.dioica species has also been studied by the same conseption 
in 2010-2011 (Figure 2. and Figure 3).

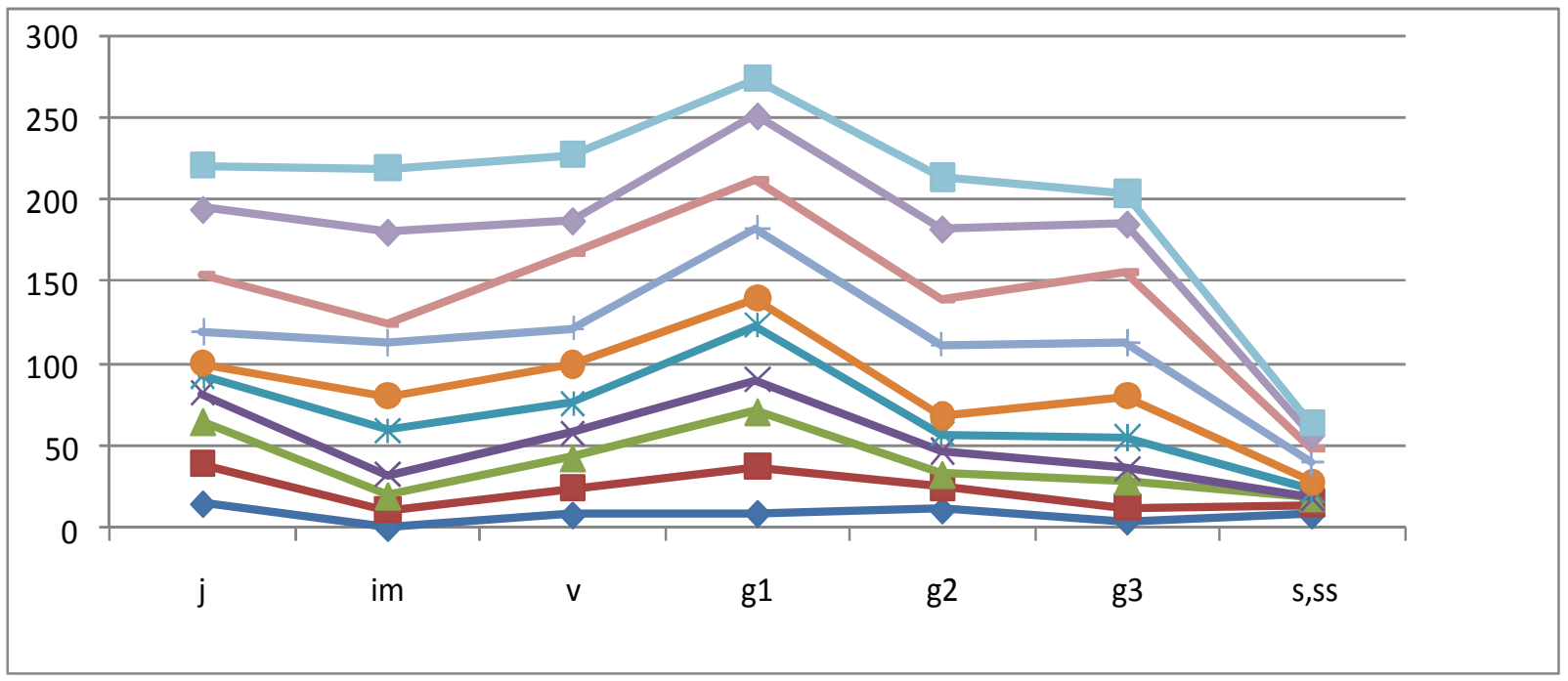

Figure 2. Ontogenesis Structure of the Urtica dioica species in 2010.

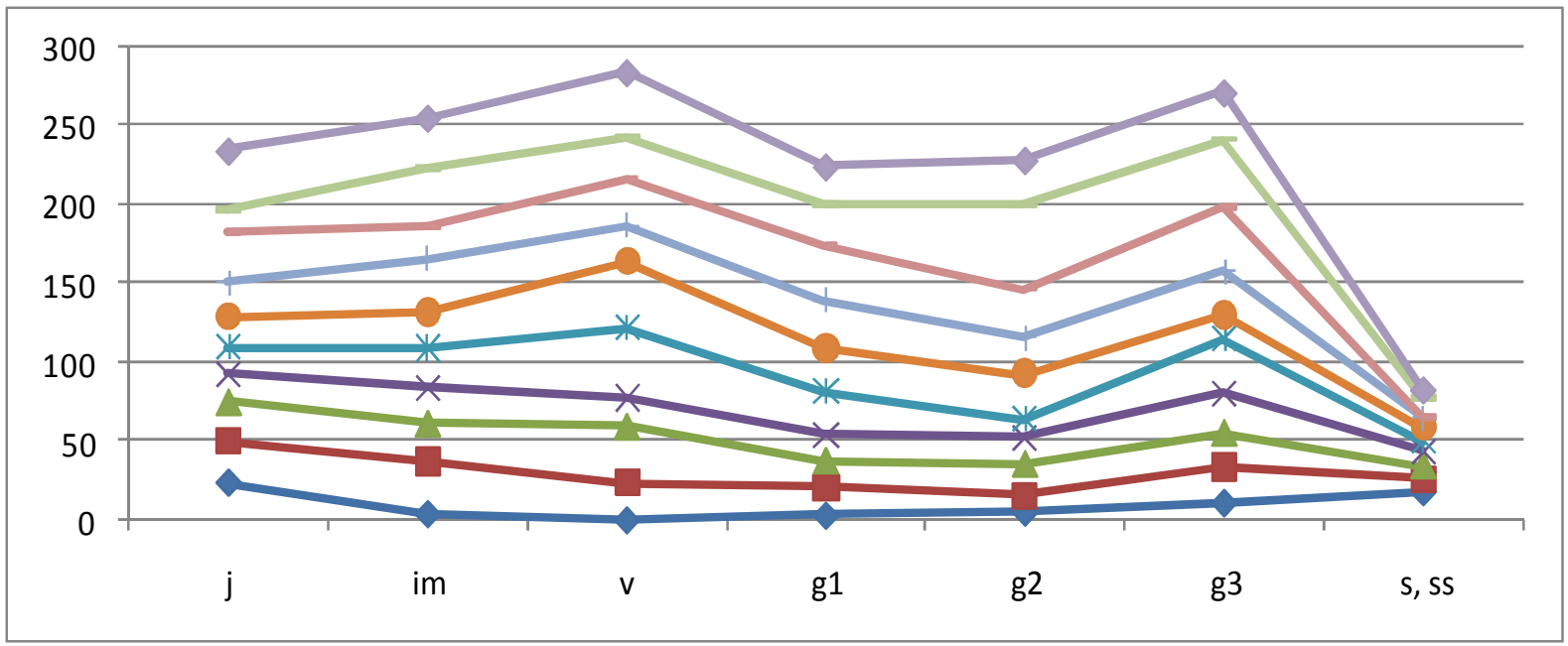

Figure 3. Ontogenesis Structure of the Urtica dioica species in 2011

It is clearly seen from the diagrammes that ontogenesis structure of the U.dioica species in the regions (The Nakhichevan AR, The Small Caucasus and the Great Caucasus) are the same, i.e. the aged individuals (s,ss) were being sharply decreased in the populations. Generation of new individuals, abondance of ( $\mathrm{j}$, im and $\mathrm{v}$ ) phases and also the generative development is in the maximum limit $\left(\mathrm{g}_{1}-\mathrm{g}_{3}\right)$ prove it once more.

In the same years a cenological evaluation at the natural phytocenoses of another medisinal plant Astragalus dasyanthus Pall.species has been carried out; a keen narrowing was observed at its populations. 3-yeard integrated ontogenic structure of the plant were specified in diagramme 4 . 


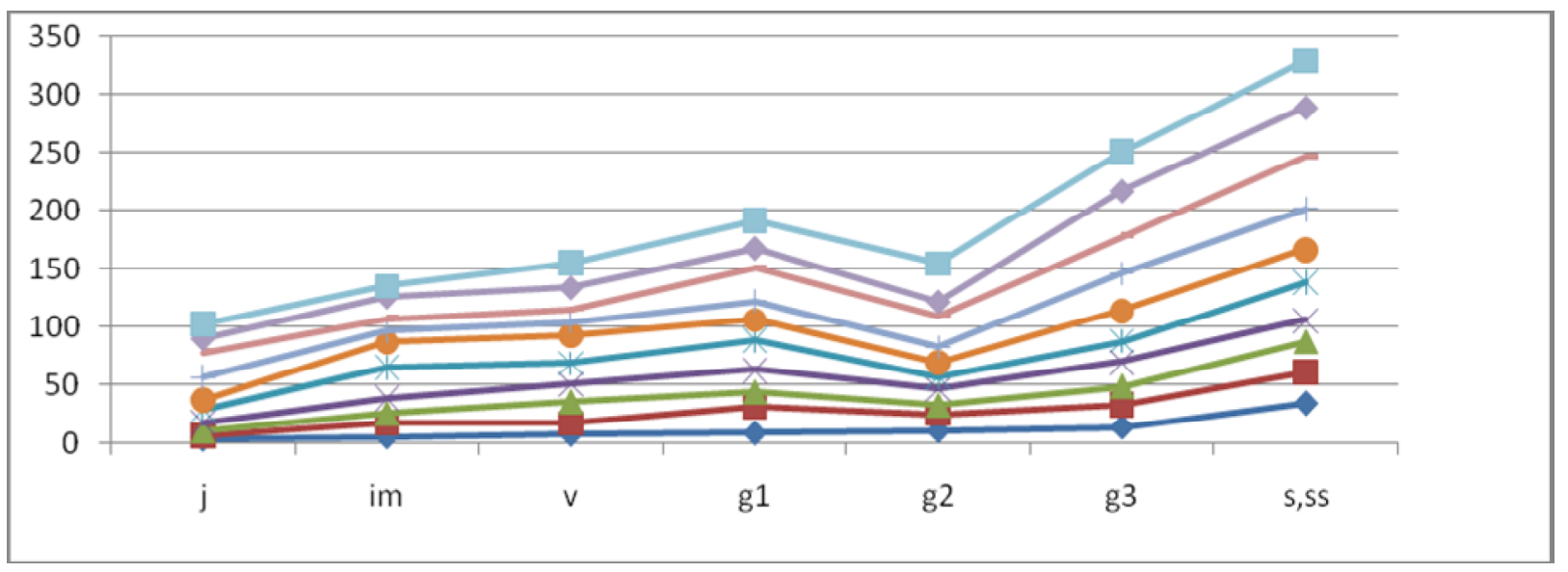

Figure 4. Cenopopulation structure of Astragalus dasyanthus species according to 2009-2011 years.

As it is seen from the diagramme individiuals belonged to sinile and subsinile periods i.e. aged ones of A.dasyanthus species at natural populations were gradually increased and the sum of the new individuals in common populations were not more than 150 . And instead of it amount of the aged individuals were not more than 300 .

I'd note that mainly the root and leaf of A.dasyanthus species are used as medicinal herb. As it has got sedative, hypotensive and vasohypotonic features it gives a good effect at treatment of deseases as: neurosis, hypotenia, chronical cardio-vascular deffect of I-II degree, at keen and chronical nefritis. Instruction of reciept: a spoonful plant is extracted in $250 \mathrm{mg}$ boiled water; the medicine is taken 3 times a day 20-40min after the meal. It is at the same time diuretic.

As a result of anthropogenic stresses decrease of the plant has been registered and there is a probability of to be undergoing to threat of lost in near future. It seems the roots of young plant are systematically collected and used by people that influences to the decrease of the plant. We consider the plant can be made to return back to its previous status by its reintroduction in its spread areas. Results of such researches carried out in natural populations can assist prelimineary study of the situation in the ecosystem and prevent such possible treats.

\section{References}

Asgerov A. M. (2005-2008). Higher plants of Azerbaijan. Baku: 'Elm'.l(3).

Davis G. E. (1933). Design elements of monitoring programs: the necessary ingredients for success. Environ and Assessment. 26, 99-105. http://dx.doi.org/10.1007/BF00547489

Hajiyev V. J, \& Musayev S. H. (1996). Plants and plant formations recommended for the Red and Green Books of Azerbaijan. Baku, P/h 'Elm', 40. 
Ibadullayeva S., N. Movsumova, H. Gasymov \& T. Mamedli. Protection of some rare and endangered vegetable plants in the flora of the Nakhichevan AR (2011). International Journal of Biodiversity and Conservation, 3(5), http://www.academicjournals.org/ijbc ISSN 2141-243X @2011 Academic Journals

Ibadullayeva S., N. Movsumova, M.Shahmuradova, T. Mamedli \& M.Seidov. (2010). Structure and productivity of coenopopulations Daucus carota L. (Apiaceae Lindl.) in flora of Azerbaijan. Sankt-Petersburg, Journal of Plant Resource, 2(3), 49-56.

Ibadullayeva S., N. Movsumova, (2011) Structure and productivity of ceonopopulations of the Salvia limbata C.A.Mey. species in the Duzdag phytocenological complex. ANAS Biological serials Journal News, 11(1). 106-111.

Ibadullayeva S. J. (2010). Vegetation Cover Of Azerbaijan. Collection of scientific works (traces) of the Botany institute ANAS, 7-15.

IUCN Red List Categories \& Criteria. (2003). Version 3.1. IUCN Species Survival Commission. IUCN, Gland, Switzerland and Cambridge: UK. ii + 30 pp.

Lavrenko Y. M. (1959). The basic laws of vegetative communities and the ways of their study. Moscow. Field Geobotany. 1, 13-75.

The Red Book of the Azerbaijan SSR. (1989). Baku, P/h 'Ishyg', 554

\section{Copyright Disclaimer}

Copyright reserved by the author(s).

This article is an open-access article distributed under the terms and conditions of the Creative Commons Attribution license (http://creativecommons.org/licenses/by/3.0/). 